\title{
Philosophical Reflections: Critical Analysis of Learning Strategies for Science Practicum during the COVID-19 Pandemic
}

\author{
Budiyono Saputro1, Muh Saerozi ${ }^{2}$, Fadhil Ardhiansyah ${ }^{3}$ \\ 1,2State Institute of Islamic Studies (IAIN) Salatiga, Salatiga, Indonesia \\ ${ }^{3}$ Asosiasi Dosen Tadris IPA Indonesia, Salatiga, Indonesia
}

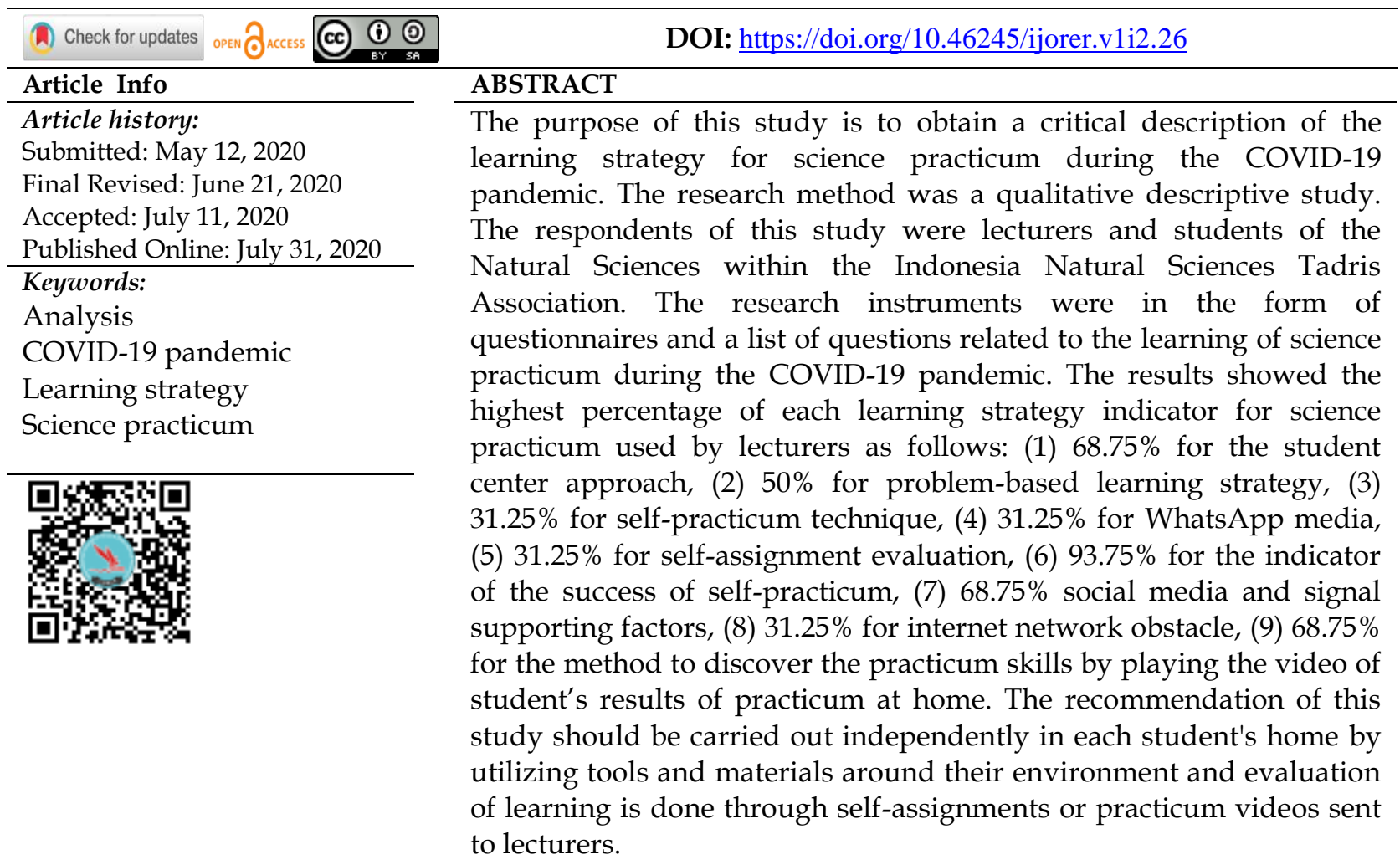

\section{INTRODUCTION}

Science learning is one of the scientific studies that are closely related to technology, covering aspects of products, processes, scientific attitudes, and applications. Science learning as a product in the form of knowledge consists of concepts, principles, laws, and theories that can contribute to the formation of a creative generation. Thus, the direction of the study of science learning helps students to become an excellent generation and be able to compete in all conditions (Maulana et al., 2019). Another advantage can also be seen from the object of the study of science learning in examining global issues, especially with the emergence of various changes that occur rapidly in the 21st century (Atista \& Kuswanto, 2018). These changes, especially in the field of education, are that there have been changes in the educational paradigm from instructive to constructivist philosophy causing changes in the need for education as we know as 21st-century education in the industry 4.0 era (Maulana et al., 2019).

Universities at the level of higher education as a place for learning activities are required to prepare reliable graduates in utilizing various kinds of advanced technology (Solikhin et al., 2018) to compete for employment (Sahida \& Zarvianti, 2019). 
Another important change in the field of education is also shown recently with the outbreak of the Coronavirus Disease 2019 (COVID) 19 pandemic. All learning activities at all levels of education, especially at the university, undergo a transformation, in which educators could not directly instruct learning and it is transferred to virtual media, while assignment and evaluation of learning is carried out through online learning (Erduran, 2020). This change is predicted to continue for a long time, especially in Indonesia with the fourth largest population in the world (Djalantae et al., 2020). This situation also marks a new challenge for the implementation of science learning (Erduran, 2020). As we know, some science learning studies require practicum activities to equip students in welcoming the 21st-century education (Aththibby et al., 2018).

Some science learning researches are very competent in addressing the issue of changes in the education sector. As is done in the science practicum activities related to the growth and development of living things with an online-based virtual lab that can increase the knowledge, skills, and creativity of students (Widodo et al., 2016). But keep in mind that these activities would take place effectively if there are supports of educational resources (Astuti, 2015). In fact, there are still many non-sustainable educational resources (Aththibby et al., 2018). Thus, it is necessary to carry out a critical analysis of learning strategies for an effective and efficient science practicum during the COVID-19 pandemic. The critical analysis aims to illustrate the further application that to guarantee the continuation of science practicum during the COVID-19 pandemic, a philosophical analysis is needed.

Since the establishment of the COVID-19 pandemic emergency status in Wuhan, China, all learning activities at all levels of education have changed towards online learning. This situation has been followed in various parts of the world, especially in Indonesia. Science learning that is usually carried out face-to-face (conventional) is changed by involving distance-oriented technology through online learning (Erduran, 2020). It aims to minimize the number of figures exposed to the impact of COVID-19 (Djalantae et al., 2020).

The pandemic situation makes pioneers for educational institutions or universities competing to develop and provide science (biology, physics, and chemistry) learning platforms for educators and students to carry out virtual learning activities (Erduran, 2020). Science learning which in essence requires practical activities with real objects also undergoes adjustments and changes (Erduran, 2020). Like biology that studies the relationship between living things and the environment, physics that learns about changes and natural phenomena and objects that exist around humans, and chemistry that studies everything related to particles, atoms and chemicals in products consumed or used by humans, science practicum is transferred to virtual objects by reconstructing students' learning environments (Astuti, 2015; Hindriana, 2016; Wanida \& Atun, 2019).

Learning science practicum is very important to do, even during a pandemic situation with all the limitations that exist in the education sector (Erduran, 2020). This is based on the fact that apart from supporting the learning material, practical activities are very useful in, including: 1) generating motivation to study science independently (Arista \& Kuswanto, 2018), 2) developing basic skills in conducting experiments (Hayati et al., 2018), 3) improving critical thinking skills (Royani et al., 2018), and 4) training students' creative thinking skills (Sahida \& Zarvianti, 2019).

The learning strategy itself is the most important activity in achieving learning objectives in class (Haikonen et al., 2017). Science learning strategies during the 
pandemic era must be designed in such a way as to involve a proactive element between educators and students to train the domain of knowledge, skills, and attitudes as a scientist. As well as reactive elements to overcome the constraints or obstacles of limited educational resources (Etiubon \& Udoh, 2017).

The following are science practicum learning strategies that can be carried out during the pandemic era, both virtual and real (practicum assignments are carried out independently or guided). Virtually, some have been implemented using smartphones with problem-based technique that can train creative thinking skills (Sahida \& Zarvianti, 2019). Then inquiry-based techniques can train independent learning and collaborative abilities (Wanida \& Atun, 2019). Meanwhile, in real terms, it is carried out with a guided-discovery technique that can train students' science process skills (Hayati et al., 2018). The implementation of real science practicum learning could be done well if educators design guidelines containing rules and regulations, materials, space, and time management as well as students' commitment to the responsibilities of practicum activities (Etiubon \& Udoh, 2017).

Both virtual and real science practicum learning during the pandemic era must of course involve technology as the operator, sender, and recipient of the results of practicum activities (Erduran, 2020). The use of technology in science practicum learning has advantages that enable students to dig deeper into science and technology contents in its application, while also being able to practice critical thinking skills in solving a problem and creativity in designing science technology if it is done on a project basis (Chen et al., 2012).

In the previous study, it has been explained several advantages of virtual and real science practicum learning. Meanwhile, the views on the weaknesses of these types of practicum have not been explained more deeply. All science practicum activities during the pandemic era involve technology, in virtual practicums, although they have been designed in such a way but still have weaknesses in facilitating students' emotional power (Widodo et al., 2016). Another disadvantage of virtual science practicum implementation is in the form of low students' laboratory skills such as making incisions, having no direct experience in handling living organism specimens of and is sometimes constrained by technological problems that interfere with the website (Flowers, 2011).

Whereas the real practicum is felt to be very structured and only for verification, so that it less arouses the curiosity of students. Besides, the exploration capability of students is also limited and it does not provide time flexibility to observe objects (Widodo et al., 2016). Through some of these views, it is best if virtual and real science practicum learning are combined in several scientific studies. Educators need to pay attention to the strategy of the order of the type of practicum that combines virtual and real practicum. Providing direct experience through real practicum followed by virtual practicum is a recommended alternative (Widodo et al., 2016; Aththibby et al., 2018).

\section{RESEARCH METHOD \\ Research Goal}

This research method used descriptive research. The research respondents were lecturers and students of the study programs at the Indonesia Natural Sciences Tadris Association. The sampling technique was purposive sampling. The research instruments were in the form of questionnaires and a list of questions related to science practicum learning during the COVID-19 pandemic era. 


\section{Data Collection}

Data obtained from respondents through the answers to the questionnaires concerning learning strategies for science practicum during the COVID-19 pandemic era and the effectiveness of learning strategy indicators.

\section{Data Analysis}

The data analysis technique in this study was descriptive statistics, by calculating the frequency, the percentage of each indicator of the strategy and effectiveness questionnaires and making histograms.

\section{RESULTS AND DISCUSSION}

The detailed results of the percentage of learning strategies for science practicum during the COVID-19 pandemic era are presented in Table 1-20.

Table 1. The learning approaches for science practicum in the COVID-19 Pandemic.

\begin{tabular}{clcc}
\hline Number & Type of Approach & Frequency $(\mathbf{n}=\mathbf{1 6})$ & $\mathbf{0}$ \\
\hline $\mathbf{1}$ & Student center & 11 & 68.75 \\
\hline $\mathbf{2}$ & Assignment & 1 & 6.25 \\
\hline $\mathbf{3}$ & Constructivism & 1 & 6.25 \\
\hline $\mathbf{4}$ & Contextual & 1 & 6.25 \\
\hline $\mathbf{5}$ & on line & 2 & 12.5 \\
\hline & Total & 16 & 100 \\
\hline
\end{tabular}

Based on Table 1, the learning approaches for science practicum during the COVID19 pandemic era conducted by the lectures of the Natural Sciences Tadris Study Program, Tarbiyah, and Teaching Sciences Faculty, State Institute of Islamic Studies (IAIN) Salatiga are $68.75 \%$ using student center approach, $12.5 \%$ using online learning approach, while assignment, constructivism and contextual approaches are $6.25 \%$ respectively.

Table 2. Effectiveness of learning approaches for science practicum during the COVID19 pandemic.

\begin{tabular}{clccc}
\hline Number & & Criteria & Frequency & \% \\
\hline $\mathbf{1}$ & Effective & & 43 & 66.2 \\
\hline $\mathbf{2}$ & Ineffective & 22 & 33.8 \\
\hline & Total & & 65 & 100
\end{tabular}

Table 2 is the confirmed percentage of the effectiveness of learning approaches for science practicum during the COVID-19 pandemic era used by lecturers collected from 65 students with $66.2 \%$ of the results answered effectively.

Table 4. Effectiveness of learning strategies for science practicum during the COVID-19 pandemic.

\begin{tabular}{clccc}
\hline Number & & Criteria & Frequency & \% \\
\hline $\mathbf{1}$ & Effective & 41 & 63.1 \\
\hline $\mathbf{2}$ & Ineffective & 24 & 36.9 \\
\hline & Total & 65 & 100 \\
\hline
\end{tabular}


Table 4 is the percentage of the effectiveness of learning strategies for science practicum during the COVID-19 pandemic with 65 student respondents which obtaining a result that $63.10 \%$ of the learning strategies used by lecturers in the learning of science practicum during the COVID-19 pandemic era is effective.

Table 5. Learning techniques for science practicum during the COVID-19 pandemic.

\begin{tabular}{clcc}
\hline Number & Learning Techniques & Frequency & $\mathbf{\%}$ \\
\hline $\mathbf{1}$ & Question and Answer & 3 & 18.75 \\
\hline $\mathbf{2}$ & Virtual & 3 & 18.75 \\
\hline $\mathbf{3}$ & Self-Practicum & 5 & 31.25 \\
$\mathbf{4}$ & Assignment & 2 & 12.5 \\
\hline $\mathbf{5}$ & Demonstration & 2 & 12.5 \\
\hline $\mathbf{6}$ & Discussion & 1 & 6.25 \\
\hline & Number & 16 & 100 \\
\hline
\end{tabular}

Table 5 is the percentage of learning techniques for science practicum during the COVID-19 pandemic era practiced by lecturers with the highest percentage is in selfpracticum technique, namely $31.25 \%$.

Table 6. Effectiveness of learning techniques for science practicum during the COVID19 Pandemic.

\begin{tabular}{clcc}
\hline Number & \multicolumn{1}{c}{ Criteria } & Frequency & \% \\
\hline $\mathbf{1}$ & Effective & 33 & 50.8 \\
\hline $\mathbf{2}$ & Ineffective & 32 & 49.2 \\
\hline & Total & 65 & 100 \\
\hline
\end{tabular}

Table 6 is the confirmation of 65 students about the effectiveness of science practicum learning techniques during the COVID-19 pandemic era, in which $50.8 \%$ of its result is effective, as seen in Table 6.

Table 7. Learning media for science practicum during the COVID-19 Pandemic.

\begin{tabular}{clccc}
\hline Number & \multicolumn{1}{c}{ Types of Strategy } & Frequency & \% \\
\hline $\mathbf{1}$ & Whatsapp Group & 5 & 31.25 \\
\hline $\mathbf{2}$ & Google Classroom & 1 & 6.25 \\
\hline $\mathbf{3}$ & Phet Application & 3 & 18.75 \\
\hline $\mathbf{4}$ & Video/Youtube & 6 & 37.5 \\
\hline $\mathbf{5}$ & Email & 1 & 6.25 \\
\hline & Total & 16 & 100
\end{tabular}

Table 7 is the percentage of learning media for science practicum during the COVID19 pandemic era done by lecturers with the highest percentage was obtained by video/YouTube media of 37.5\%, WhatsApp Group of 31.25\%, PhET Application of $18.75 \%$ and google classroom of $6.25 \%$. 
Table 8. Effectiveness of learning media for science practicum during the COVID-19 pandemic.

\begin{tabular}{cccc}
\hline Number & Criteria & Frequency & \% \\
\hline $\mathbf{1}$ & Effective & 40 & 61.5 \\
\hline $\mathbf{2}$ & Ineffective & 25 & 39.5 \\
\hline & Total & 65 & 100
\end{tabular}

Table 8 is the confirmation of 65 students about the effectiveness of media learning for science practicum during the COVID-19 pandemic era in which $61.5 \%$ of the result is effective.

Table 9. Learning evaluations for science practicum during the COVID-19 pandemic.

\begin{tabular}{cccc}
\hline Number & Types of Strategy & Frequency & $\mathbf{0}$ \\
\hline $\mathbf{1}$ & On line & 4 & 25 \\
$\mathbf{2}$ & Self-Assignment & 5 & 31.25 \\
$\mathbf{3}$ & Video & 4 & 25 \\
\hline $\mathbf{4}$ & Report & 3 & 18.75 \\
\hline & Total & 16 & 100 \\
\hline
\end{tabular}

Table 9 is the percentage of learning evaluations for science practicum during the COVID-19 pandemic era conducted by lecturers with the highest percentage is obtained by self-assignment of $31.25 \%$.

Table 10. Effectiveness of learning evaluations for science practicum during the COVID-19 pandemic.

\begin{tabular}{cccc}
\hline Number & Criteria & Frequency & \% \\
\hline $\mathbf{1}$ & Effective & 39 & 60 \\
\hline $\mathbf{2}$ & Ineffective & 26 & 40 \\
\hline & Total & 65 & 100
\end{tabular}

Table 10 is the confirmation of 65 students about the effectiveness of learning evaluations for science practicum during the COVID-19 pandemic era, in which $60 \%$ of the result is effective.

Table 11. Success indicators for science practicum learning during the COVID-19 pandemic.

\begin{tabular}{cccc}
\hline Number & Types of Strategy & Frequency & $\mathbf{\%}$ \\
\hline $\mathbf{1}$ & Showing Products & 1 & 6.25 \\
\hline $\mathbf{2}$ & Capable of Doing Self Practicum & 15 & 93.75 \\
\hline & Total & 16 & 100
\end{tabular}

Table 11 are the percentage of success indicators of science practicum learning during the COVID-19 pandemic era conducted by lecturers with the highest percentage is obtained by students being able to do self-practicum, namely $93.75 \%$. 
Table 12. Effectiveness of success indicators for science practicum learning during the COVID-19 pandemic.

\begin{tabular}{cccc}
\hline Number & Criteria & Frequency & \% \\
\hline $\mathbf{1}$ & Effective & 29 & 44.6 \\
\hline $\mathbf{2}$ & Ineffective & 36 & 55.4 \\
\hline & Total & 65 & 100
\end{tabular}

Based on Table 12, the confirmation of 65 students about the effectiveness of success indicators for science practicum learning during the COVID-19 pandemic era obtained a result that $60 \%$ of it is effective.

Table 13. Readiness of students in science practicum learning during the COVID-19 pandemic.

\begin{tabular}{cccc}
\hline Number & Readiness & Frequency & $\mathbf{\%}$ \\
\hline $\mathbf{1}$ & Ready & 11 & 68.75 \\
\hline $\mathbf{2}$ & Not Ready Yet & 2 & 12.50 \\
\hline $\mathbf{3}$ & Not Ready & 3 & 18.75 \\
\hline & Total & 16 & 100
\end{tabular}

Table 13 are the percentage of students' readiness in science practicum learning during the COVID-19 pandemic era conducted by lecturers with the highest percentage is obtained by students who are ready to follow the learning activities, namely $68.75 \%$.

Table 14. Effectiveness of the readiness in science practicum learning during the COVID-19 pandemic.

\begin{tabular}{cccc}
\hline Number & Criteria & Frequency & $\mathbf{\%}$ \\
\hline $\mathbf{1}$ & Effective & 46 & 70 \\
\hline $\mathbf{2}$ & Ineffective & 19 & 30 \\
\hline & Total & 65 & 100 \\
\hline
\end{tabular}

Based on Table 14, confirmation of 65 students about the readiness of students in science practicum learning during the COVID-19 pandemic era obtained a result that $70 \%$ of it is effective.

Table 15. Supporting factors for science practicum learning during the COVID-19 pandemic.

\begin{tabular}{llcc}
\hline Number & \multicolumn{1}{c}{ Types of Factor } & Frequency & \% \\
\hline $\mathbf{1}$ & Communication & 3 & 18.75 \\
\hline $\mathbf{2}$ & Social media and signal & 11 & 68.75 \\
\hline $\mathbf{3}$ & Curiosity & 1 & 6.25 \\
\hline $\mathbf{4}$ & Environment & 1 & 6.25 \\
\hline & Total & 16 & 100 \\
\hline
\end{tabular}

Table 15 represents the percentages of supporting factors for science practicum learning during the COVID-19 pandemic era conducted by lecturers with the highest percentage is obtained by social media and signal by $68.75 \%$. 
Table 16. Effectiveness of supporting factors in science practicum learning during the COVID-19 pandemic.

\begin{tabular}{cccc}
\hline Number & Criteria & Frequency & \% \\
\hline $\mathbf{1}$ & Effective & 34 & 52.3 \\
\hline $\mathbf{2}$ & Ineffective & 31 & 47.7 \\
\hline & Total & 65 & 100
\end{tabular}

Based on Table 16, confirmation of 65 students about the supporting factors in science practicum learning during the COVID-19 pandemic era gained a result that $52.3 \%$ of it is effective.

Table 17. Obstacles in science practicum learning during the COVID-19 pandemic.

\begin{tabular}{cccc}
\hline Number & Types of Strategy & Frequency & \% \\
\hline $\mathbf{1}$ & Internet network & 5 & 31.25 \\
\hline $\mathbf{2}$ & Facility and infrastructure & 8 & 50 \\
\hline $\mathbf{3}$ & Group study & 3 & 18.75 \\
\hline & Total & 16 & 100 \\
\hline
\end{tabular}

Based on Table 17, the obstacles in science practicum learning during the COVID-19 pandemic conducted by lecturers of the Natural Sciences Tadris Study Program, Tarbiyah and the Teaching Sciences Faculty of the State Institute of Islamic Studies (IAIN) Salatiga are facilities and infrastructure by 50\%, internet network by $31.25 \%$ and group study of $18.75 \%$. This was after confirmation by 65 students, in which $87.7 \%$ of the result stated that there were obstacles as shown in Table 18.

Table 18. Obstacles in science practicum learning during the COVID-19 pandemic.

\begin{tabular}{cccc}
\hline Number & Criteria & Frequency & \% \\
\hline $\mathbf{1}$ & Present & 57 & 87.7 \\
\hline $\mathbf{2}$ & Not present & 8 & 12.3 \\
\hline & Total & 65 & 100 \\
\hline
\end{tabular}

Table 19. Methods to discover science practicum skills during the COVID-19 pandemic.

\begin{tabular}{cccc}
\hline Number & Types of Strategy & Frequency & $\mathbf{\%}$ \\
\hline $\mathbf{1}$ & Discussion & 5 & 31.25 \\
\hline $\mathbf{2}$ & Video of Practicum Results & 11 & 68.75 \\
\hline & Total & 16 & 100 \\
\hline
\end{tabular}

Based on Table 19 the methods to discover the science practicum skills during the COVID-19 pandemic are through discussion by $31.25 \%$ and the video of practicum results by $68.75 \%$. This was after confirmation by 65 students, in which $86.2 \%$ of them stated that the methods are effective, as shown in Table 20.

Table 20. Effectiveness of the methods to discover science practicum skills during the COVID-19 pandemic.

\begin{tabular}{cccc}
\hline Number & Criteria & Frequency & \% \\
\hline $\mathbf{1}$ & Effective & 56 & 86.2 \\
\hline $\mathbf{2}$ & Ineffective & 9 & 13.8 \\
\hline & Total & 65 & 100 \\
\hline
\end{tabular}


The COVID-19 pandemic era makes changes to learning strategies. This is done because of the government's recommendation to stay at home to avoid the transmission of the coronavirus and as an effort to cut its spread. Based on the reality in the field, in general, during the COVID-19 pandemic era, learning activities are done online. Erduran (2020) stated that the era of the pandemic has an impact on learning systems throughout the world by implementing teaching strategies that still maintain the habit of scientific thinking with online learning. Mailizar et al. (2020) show that during the COVID-19 pandemic era learning by maximizing e-learning. The science practicum course is one of the subjects that has constraints or obstacles in the conditions of the COVID-19 pandemic era. This is following the results of a survey to lecturers and students of the Natural Sciences Tadris study program within the Indonesia Natural Sciences Tadris Lecturers Association whereas the practicum materials that can be done by students at home are $75 \%$. The analysis of learning strategy indicators for science practicum during the COVID-19 pandemic era is as follows.

- Learning approaches for science practicum during the COVID-19 pandemic.

$68.75 \%$ of lectures at the Natural Sciences Tadris study program in the Indonesia Natural Sciences Tadris lecturers association use the student center approach during the COVID-19 pandemic era. This makes students active and can practice independently in their homes using tools and materials available around their homes. After being confirmed with 65 students, $66.2 \%$ stated the approach used by the lecturers in learning is effective.

- Learning strategies for science practicum during the COVID-19 pandemic.

$50 \%$ of lecturers use Problem-Based Learning in science practicum learning during the COVID-19 pandemic condition. That is because problem-based learning can make students do creativity related to tools and materials in doing a practicum following the conditions of the surrounding environment.

- Learning techniques for science practicum during the COVID-19 pandemic

$31.25 \%$ of the lecturers use self-practicum learning techniques. That is because of the COVID-19 pandemic condition and as an effort to achieve the goal of learning, namely practical skills. Every student can simply do their own practicum and make a video for proof of performance and evaluation of practicum capabilities.

- Learning media for science practicum during the COVID-19 pandemic

$37.5 \%$ of lecturers use YouTube media and their video recordings to carry out the science practicum learning during the COVID-19 pandemic era. This is due to the ease of access to getting YouTube and making their videos.

- Learning evaluation for science practicum during the COVID-19 pandemic $31.25 \%$ of the lecturers evaluate independent assignments. Independent evaluation makes it easy for lecturers and students to measure the achievement of individual learning targets. Several lecturers also conduct evaluations through practicum reports and student practicum videos and products produced by students. This is in line with the research of Caiman \& Jakobson (2019) which shows that the practice of making videos in science learning gives meaning to the learning in the aspects of students' knowledge and creativity deepening.

- Success indicators in science practicum learning during the COVID-19 pandemic Success indicator in learning, generally, is each individual can practice on their own. Based on research results, $93.75 \%$ of students can practice independently. Thus the learning of science practicum during the COVID-19 pandemic era is successful in its 
implementation. In detail, the success is because the students: (1) can express, explore problems and solve or propose solutions to problems according to practicum topics by using tools and materials around their homes, (2) can operate props, obtain data, analysis and conclude, (3) can complete the evaluation given, and show the results of experimental performance independently at each home, (4) can interpret the data of the results of virtual practicum.

- Readiness of science practicum learning during the COVID-19 pandemic $68.75 \%$ of students are ready to do a practicum in their respective homes. However, the rest is not ready because of obstacles in facilities and infrastructure.

- Supporting factors in science practicum learning during the COVID-19 pandemic $68.75 \%$ of supporting factors are social media and signals. Besides, it is also due to the ownership of equipment/mobile phones and other facilities and infrastructure.

- Learning obstacles in science practicum during the COVID-19 pandemic $50 \%$ of students are constrained by facilities and infrastructure, the difficulty of collaboration in practicum groups, internet quota, slow internet network, limited practicum tools owned by students.

The above analyses are in line with the opinions from the results of the evaluation to 65 students of the Natural Sciences Tadris study program that science practicum learning during the COVID-19 pandemic is carried out independently and guided by lecturers of the course by practicing in their homes. Self-practicum by using tools and materials by utilizing the available potential around each student's environment. During the practicum, it is documented via video. Practicum guides are made in the form of tutorial links that will be able to guide students in performing practicum. The practicum constraints are limited tools and materials, different signal quality, and group learning difficulties. Thus, when the COVID-19 pandemic struck, the learning of science practicum continues. According to Koster \& De Regt (2020), science learning continues to provide science values to students to become responsible and professional academicians.

Based on the discussion regarding the results of this study, the philosophical study that the researcher conveys is limited to the aspects of logic, epistemology, and ethics. First, in terms of logic aspect, science practicum during the COVID-19 pandemic era can be carried out by conducting self-practicum by students wherever they are with simple tools and materials to adjust the conditions of the surrounding environment. Scientific thinking and scientific results are still achieved by students. Second, in terms of the epistemological aspect, that the experience of students in practicing independently in their homes contributes to scientific thinking that can give meaning in the ability of skills, attitudes, and knowledge. Third, in terms of ethical aspect, that science practicum carried out by students independently in their respective homes is a good attitude and trains an honest, thorough and responsible attitude

\section{CONCLUSIONS}

The COVID-19 pandemic has an impact on changes in learning systems, especially science practicum learning. Based on the results of the percentage level, the results of this study can provide practicum science learning solutions during the COVID-19 pandemic by conducting practicum independently in each student's home by utilizing the tools and materials available in the surrounding environment, evaluating by 
sending a video of the practicum results to the lecturer. While the philosophical study, reflection, and analysis of science practicum learning are as follows: in the logic aspect, the science practicum during the COVID-19 pandemic can be carried out by conducting independent practicums by students wherever they are with simple tools and materials, adjusting the conditions of the surrounding environment. In the epistemology aspect, that students' self-practicum can provide good experience in terms of skills, attitudes, and knowledge. In the ethical aspect, that independent science practicum can train an honest, thorough, and responsible attitude. The results of this study recommend to lecturers to maintain the continuity of practicum subjects in the COVID-19 pandemic that can be practiced virtually or by using other social media.

\section{ACKNOWLEDGEMENTS}

Thank you to Natural Sciences within the Indonesia Natural Sciences Tadris Association for supporting data this research.

\section{REFERENCES}

Astuti, T. (2015). Manajemen praktikum pembelajaran IPA. Jurnal Manajemen Pendidikan. 9 (1), 57-64.

Aththibby, A.R., Lubis, S.P.W., \& Ardiyanti, Y. (2018). TPACK as innovation of learning science laboratory of Indonesia. International Conference on Educational Research and Innovation (ICERI). 330, 135-138.

Atista, F.C., \& Kuswanto, H. (2018). Virtual physics laboratory application based on the android smartphone to improve learning independence and conceptual understanding. International Journal of Instruction, 11(1), 1-16.

Caiman, C \& Jakobson, B. (2019). The role of art practice in elementary school science. Science \& Education, 28, 153-175.

Chen, S., Lo, H.C., Lin, J.W., Liang, J.C., Chang, H.Y., Hwang, F.K., Chiou, G.L., Wu, Y.T., Lee, S.W.Y., Wu, H.K., Wang, C.Y., \& Tsai, C.C. (2012). Development and implications of technology in reform-based physics laboratories. Physical Review Special Topics-Physics Education Research, 8(2), 1-12.

Djalantae, R., Lassa, J., Setia, M., Sudjatma, A., Indrawan, M., Haryanto.,......Mahfud, C. (2020). Review and analysis of current responses to COVID-19 in Indonesia: Period of January to march 2020. Progress in Disaster Science, 6, 1-9.

Erduran, S. (2020). Science education in the era of a pandemic how can history, philosophy and sociology of science contribute to education for understanding and solving the Covid-19 Crisis? Science E Education, 29, 233-235.

Flowers, L. O. (2011). Investigating the effectiveness of virtual laboratories in an undergraduate biology course. The Journal of Human Resource and Adult Learning, $7(2), 110-116$.

Etiubon, R. U., \& Udoh, N.M. (2017). Effect of practical activities and manual on science academic performance on solubility in urban local education authority of Akwa Ibom state. Journal of Education and Practice, 8(3), 202-209.

Haikonen, L., Toom, A., Phyhalto, K., Pletarinen, J., \& Soini, T. (2017). Student-teachers strategies in classroom interaction in the context of the teaching practicum. Journal of Education for Teaching, 43(5), 534-549.

Hayati, D.P., Bintari, S.H., \& Sukaesih, S. (2018). Implementation of the practicum methods with guided-discovery model to the student skill of science process. Journal of Biology Education, 7(1), 118-126. 
Hindriana, A.F. (2016). The development of biology practicum learning based on vee diagram for reducing student cognitive load. Kournal of Education, Teaching and Learning, 1(2), 61-65.

Koster, E. \& De Regt, H. (2020). Science and values in undergraduate education. Science $\mathcal{E}$ Education, 29, 123-143.

Mailizar, Almanthari, A., Maulina, S., \& Bruce, S. (2020). Secondary school mathematics teachers' views on e-learning implementation barriers during the COVID-19 pandemic: The case of Indonesia. EURASIA Journal of Mathematics, Science and Technology Education, 16(7), 1-9.

Maulana, I., Suryani, N., \& Asrowi. (2019). Augmented reality: Solusi pembelajaran IPA di era revolusi industri 4.0. Proceedings of the ICECRS, 2(1), 19-26.

Royani, I., Mirawati, B., \& Jannah, H. (2018). Pengaruh model pembelajaran langsung berbasis praktikum terhadap keterampilan proses sains dan kemampuan berpikir kritis siswa. Prisma Sains: Jurnal Pengkajian Ilmu dan Pembelajaran Matematika dan IPA IKIP Mataram, 6(2), 46-55.

Sahida, D \& Zarvianti, E. (2019). Development of Problem Based Learning (PBL) practicum guide to improve student Creative Thinking Skills (CTS) in basic physic subject. Journal of Education and Learning Studies. 2(1), 39-44.

Solikhin, F., Ikhsan, J., \& Sugiyarto, K.H. (2018). A need analysis in developing virtual laboratory according to the chemistry teachers. International Conference of Chemistry (ICCHEM), 1-5.

Wanida, N., \& Atun, S. (2019). Media development: Virtual laboratory base on structured inquiry in acid base titration. International Journal on New Trends in Education and Their Implication, 10(4), 12-20.

Widodo, A., Maria, R.A., \& Fitriani, A. (2016). Peran praktikum rill dan praktikum virtual dalam membangun kreatifitas siswa. Jurnal Pengajaran MIPA, 21(1), 92-102. http://dx.doi.org/10.18269/jpmipa.v21i1.670.

*Assoc. Prof. Dr. Budiyono Saputro, M.Pd. (Corresponding Author)

Science Education, Faculty of Teacher Training and Education, State Institute of Islamic Studies (IAIN) Salatiga, Indonesia.

Jl. Lingkar Salatiga KM 2 Pulutan, Sidorejo, Kota Salatiga, Provinsi Jawa Tengah Indonesia.

Email: budiyonosaputro@iainsalatiga.ac.id

Prof. Dr. Muh Saerozi, M.Ag.

Magister Program of Islamic Religious Education State Institute of Islamic Studies (IAIN)

Salatiga, Indonesia.

Jl. Lingkar Salatiga KM 2 Pulutan, Sidorejo, Kota Salatiga, Provinsi Jawa Tengah

Indonesia.

Email: saerozi2010@yahoo.com

Fadhil Ardhiansyah ${ }^{3}$

Member of Asosiasi Dosen Tadris IPA Indonesia Indonesian Natural Sciences Lecturers Association.

Jl. Lingkar Salatiga KM 2 Pulutan, Sidorejo, Kota Salatiga, Provinsi Jawa Tengah Indonesia.

Email: muslimfadhil2@gmail.com 